\title{
Learning Material Development Containing Critical Thinking and Creative Thinking Skills Based on Local Wisdom
}

\author{
Noorhapizah ${ }^{1, *}$, Akhmad Riandy Agusta ${ }^{1}$, Diani Ayu Pratiwi ${ }^{1}$ \\ ${ }^{I}$ Elementary School Teacher Education, Faculty of Teacher Training and Education, Universitas Lambung Mangkurat, \\ Banjarmasin, Indonesia \\ *Corresponding author. Email: noorhapizah@ulm.ac.id
}

\begin{abstract}
The problem with this research is the unavailability of teaching materials which is containing critical, creative and logical thinking skills improvement based on local wisdom. While the development of critical thinking and creative thinking skills becomes one of the great goals that are expected to get a productive future generation. This research use research and development methods that will develop products in the form of teaching materials and textbooks containing critical, creative, and logical thinking skills improvement based on local wisdom. The research design refers to the Borg \& Gall design which consists of 10 steps. the result mentioned that thematic textbooks containing critical thinking, creative thinking and logical thinking based on local wisdom deserve to be used, have effectiveness for the fifth grade of elementary school based on evaluation from the material draft expert, media expert, language expert and field test. Based on the results, it can be concluded that there is a significant difference between the results of the experimental class posttest and the control class posttest scores.
\end{abstract}

Keywords: learning materials, critical thinking skills, creative thinking skills, logical thinking skills, local wisdom

\section{INTRODUCTION}

The important of thinking ability and communication in the industrial revolution 4.0, push every country's progress was not only concern on development of natural resources and huge per capita income. The country's progress must be manifest through lifeskills and character human resources. This is because facing challenges in the future requires human resources to compete and make every side of life will be easy to do. In the face of such challenges, human resources must have the important skills such as thinking skills in the face of competition in this era. Future human resources have big challenges, they must have high quality ability to process information, have critical thinking, can communicate well to other persons and to collaboration with other (Rachmawati, 2010; Suriansyah, 2018). Beside that skills, Shoimin (2016) mentioned that there are 4 basic skills that students must have in the face of that future challenge, they are Critical Thinking, Creativity, Communication and Collaboration (Barry, 2012; Wagner, 2010; Hasratuddin dkk, 2014; Istianah, 2013; Khoiri \& Supriyanti, 2017; Kemendikbud, 2017).

Reflecting on the important skills to be owned by the next generation on industrial revolution 4.0, it's time to bring learning activity based on thinking skills, we called as high order thinking skills that human resources must have in the future. The first thinking skill is critical thinking. It can help next generation to think rationally in can solve every problem and give their win solutions or alternative to break every problem, it meand that critical thinking skill need to be develop from elementary education period (Hasratuddin dkk, 2014; Istianah, 2013). Critical thinking and other thinking skills that must have by the students as young generation give implications for the education world, it makes challenge to all of teachers and stakeholders to empower its trainees with various skills so that it can have provisions to achieve the next generations' future (Sani, 2015).

Another thinking skill that needs to be developed for next generation is creative thinking skills. In the $21 \mathrm{st}$ century, teachers generally must establish minimum $3^{\text {rd }}$ level of cognitive aspect on taxonomy to make advanced students' thinking skills. Creative thinking skill is also seen as thinking skills that can help learners when asked where and how to achieve and deduced, so that creative thinking skills can help learners survive in the information and globalization era (Suparlan, 2005; Gillies \& Boyle, 2009; Sumarmo \& Nishitani, 2010; Shoimin, 2014). Critical thinking and creative thinking skills are the focus skills that must develop and combine to learning activity on $21 \mathrm{st}$ century (Sibarani, 2013).

Both of skills can include optimally on learning activity if there is a professional teacher performing innovative teaching in the classroom. A professional teacher was required and make best planning to present 
their expertise before the class. One of those skills is the ability to deliver information to students. To be able to deliver effective and efficient lesson, teachers need to prepare teaching materials that integrate the strategies and the innovative instructional models. In order to achieve the objectives of learning, each teacher is required to have the ability to make and prepare teaching materials in accordance with the requirements for the purpose of learning and to incorporate the strategic tools of learning that will be applied (Anitah, 2010; Tendrita, Mahanal \& Zubaidah, 2017; Uno \& Mohamad, 2012).

Based on that mind, teachers' needs to develop a teaching material that contain critical and creative thinking skills in the industrial revolution 4.0. Therefore, it is important for teachers to design systematically teaching materials that are consistent with the vision to improve students' ability to explore knowledge independently and to develop their thinking skills with every way. The compiled teaching material should be mindful of the presence of appropriate strategies and models to realize learning processes necessary to develop the students' potential.

Teacher ability to develop teaching materials to facilitate a learning activity based on critical thinking and creative thinking skills is described on prior research by Agusta \& Noorhapizah (2019) that just 39,5\% of teachers in Banjarmasin who understand and can make lesson plan contain critical thinking and creative thinking or about $60,5 \%$ elementary school teacher in a Banjarmasin city is not understand with concept of critical thinking and creative thinking and held learning activity based on both skills.

The same study also revealed the learning process carried out within a class of $82.35 \%$ public elementary school teachers in Banjarmasin city, never make lesson activity which integrating critical thinking and creative thnking. This fact causes of teachers less knowledge about high order thinking skills and they are not having teaching materials which contain high order thinking skills such as critical thinking and creative thinking skills that make it easier for a teacher to carry out the expectation of learning process of industrial revolution 4.0.

Another reality demonstrated by study PISA on 2015 that marks the achievement of students in Indonesia, the result show that we get rank only 69 of 72 countries. These results are supported by the study from TIMSS (Trends in International Mathematics and Science Study), Indonesian students have ranked 36 of 49 countries in scientific thinking skills. The results demonstrated by these two international assessment departments concern to student's achievement on thinking skills. The achievement which remains a concern is shown by the results of the Indonesian assessment from human development index (HDI), which places 116 of 189 countries. Various assessments that place Indonesia at the low level must be immediately get solutions in long or short term.

Other problem is mentioned that low quality of learning is caused by teacher's ability to prepare learning activity with an innovative, creative, effective, fun and based on 21st-century skills. Teachers are still comfortable with the practical learning process of using even a simple learning activity without using an instructional model on learning activity that can motivate students to learn and potentially develop the students' ability. While the use of the instructional model can lead to an educational objective by giving the experience of democratic individuality and fostering students' scientific and social attitudes by using society as learning resources.

Furthermore Agusta, Setyosari \& Sa'dijah (2018) mentioned that learning process on elementary school in Banjarmasin city is still a transfer of knowledge and has not developed a student's creativity. The same problem was stated by Pratiwi \& Sofiawati (2018) that elementary school in a Banjarmasin city still has not develop the student independence in learning. Similar conditions are mention by Fauzi \& Fikri (2018) That the learning process on elementary school in Banjarmasin city still makes cognitive as the primary requirement.

Other research results on Banjarmasin are found that most teachers still use unstructured lesson plan without contain high order thinking skills in both the design of learning activity and evaluation activities. More than $90 \%$ of the number of public elementary school teachers in Banjarmasin has never done the development of teaching materials. Most teachers carry out the learning process in a practical way and have not implemented innovative instructional models that can develop high order thinking skills yet, it makes the learning activity be monotonous and can make students has low motivation on learning process. Learning activity is still a transfer of knowledge and has not placed students as centers of learning yet.

This results in students' engaging on learning process, recording materials, talking exercises, occasionally using group discussion and work but not based on cooperative skills. This kind of learning process has certainly not developed students' thinking skill. Also concerning is the evaluation activity which only focus on cognitive achievement, not achieves affective and psicomotoric assessments yet (Norfuad \& Suriansyah, 2019; Agusta, Setyosari \& Sa'dijah 2018; Aqli \& Suriansyah 2018; Fahlivi \& Asniwati 2018; Yundiapi \& Aslamiah 2018; Nenestalia \& Aslamiah 2018; Sholehah \& Asniwati 2017; Nurmala \& Suriansyah 2017).

To solve the problems and achieve the goals of curriculum 2013, we must improve quality of lesson plan and learning materials that is used by teacher to determining the key success of curriculum 2013. Our curriculum 2013 make design of learning on elementary school with integrative thematic based learning and use textbooks in every theme. Thematic integrative is a learning approach that integrates various competencies from various subjects into various themes (Kemendikbud, 2013). Each theme consists of 4 subthemes, each subtheme consists of 6 learning. A key characteristic of curriculum 2013 is that there is no learning unit, but the learning charge is combined into one learning that integrates two to 
three teaching. The themes arranged in student study textbooks are drawn from the daily and environmental conditions around the students.

Based on textbook observations in elementary schools, it has not contained with critical and creative thinking skills. Based on the observations made by researchers in 20 elementary schools representing the school in the northern village sub-district, the results are that learning activities have not been able to develop critical thinking and creative thinking skills. This is because teachers do not have such deep knowledge to make lesson plan based on critical thinking and creative thinking skills, the teaching materials used are only teachers' books and student books.

Coupled with a learning process that is carried out without using an instructional model that integrates the development of critical thinking and creative thinking skills. Furthermore, it is noted that some teachers have less knowledge and perception of books that are provided by the government. Some teachers consider the book to be the only source for study and not take the initiative to seek more supplement material from other sources (source: Observation of a 20 elementary school area in northern Banjarmasin sub-district in September 2019).

Furthermore, on south Kalimantan we are not found the teaching material that is containing contextual content. The student's daily environmental conditions are closely related to local wisdom. Sibarani (2013) Concludes that local wisdom is pure knowledge (indigineous knowledge) or society local intelligence derived from the virtues of cultural tradition to govern the order of people's lives in order to achieve community progress in the creation of peace as well as increased public well-being. Local wisdom may include local knowledge, local skills, local intelligence, local resources, local social processes, local normative, and local mores. The teaching material containing local wisdom will give meaning to students who are attending the learning process. But unfortunately, a local suburb of south Borneo hasn't been explicitly introduced into the teaching material. While it is clear that one of the teaching characteristics is a characteristic of space, it implies the learning content is tailored to the environmental situations and conditions surrounding students (Hosnan, 2016).

If this condition not corrected, it will result in low of learners' ability to solve problems, creating new innovations and viewing a problem with logical thinking.
Developing critical and creative thinking skills will require innovation of thematic material with local wisdom. Such innovation is built in the development of critical thinking and creative thinking skills based on local wisdom. textbooks based on local wisdom were development of thematic textbooks in fifth grade class. This book can be made as a supplement to curriculum 2013 teacher books and students' books. The extent to which this innovation will achieve the realization of textbooks contain local wisdom that can be used globally by introducing local wisdom to each region.

Based on the formulation of problems, the purpose of this research and development is create and produce learning material based local wisdom for fifth grade elementary school and describe the effectiveness and appropriateness learning material containing critical thinking and creative thinking skills improvement based on local wisdom for fifth grade students on elementary school.

\section{METHOD}

This research use research and development method because it will develop teaching matearials containing critical thinking and creative thinking skills improvement based on local wisdom theme 8 "Lingkungan Sahabat Kita" Subtheme 3 "Usaha Pelestarian Lingkungan" on fifth grade of elementary school. Based on Borg \& Gall (1983) research and development (R\&D) in education covering ten steps. Are the steps in R\&D: (1) research and information collecting; (2) planning; (3) develop preliminary form of product; (4) Preliminary field testing; (5) main product revision; (6) main field testing; (7) operational product revision; (8) operational field testing; (9) final product revision; dan (10) dissemenation and implementation. Research and development in accordance with the steps of the research and development model according to Borg and Gall as follows (Figure 1).

The feasibility test of the product was undertaken to know the level of worthiness. Based on deficiencies in test results, researchers revised the areas that were still less deserving, resulting in a viable product to be used. The design of the product test was done to get the data that would be used to know the deficiencies of the product that were developed and it will be revision of the product. The purpose of the test is to know the appropriateness and effectiveness of the textbook. A phase of the trials of this product can be found in the following Figure 2.

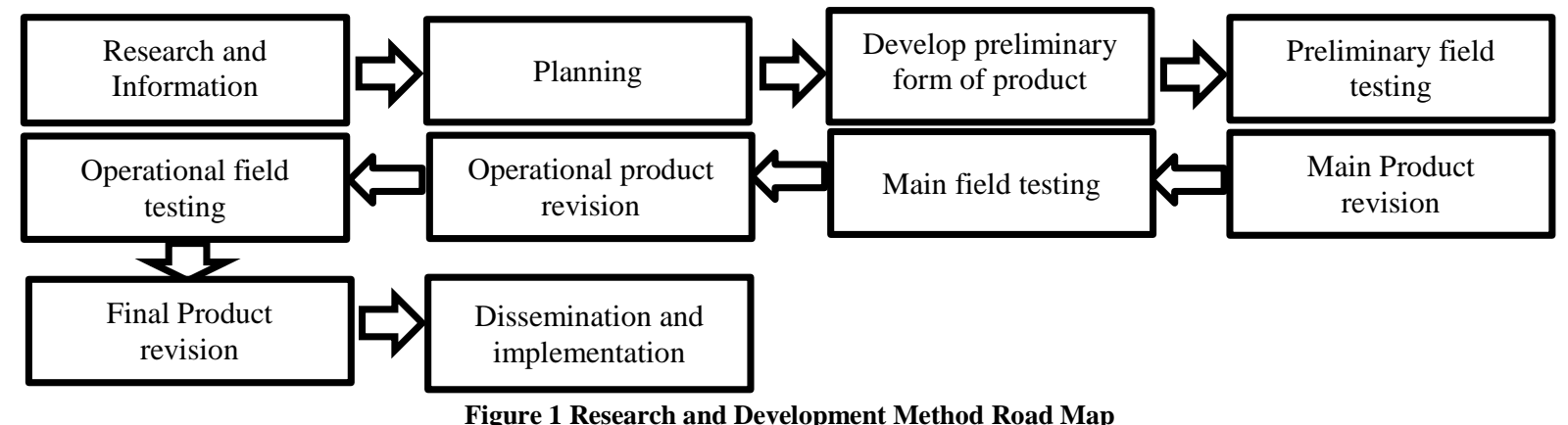

Figure 1 Research and Development Method Road Map 


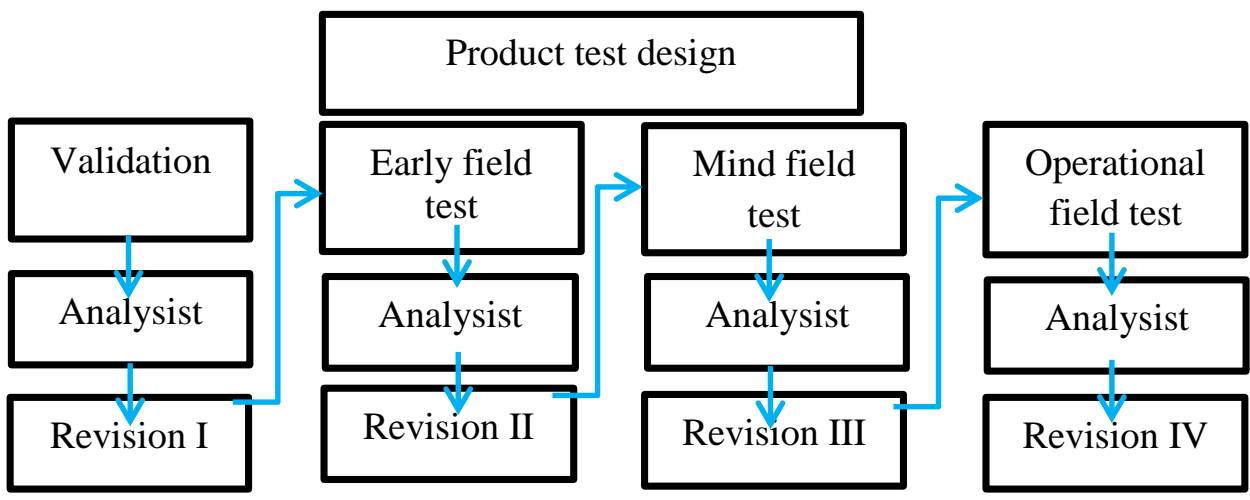

Figure 2 Product Test Design

The stages under are the validation of materials experts, media experts, and book designers; Early trial (limited trial) It was done in the fifth grade Karang Mekar 1 elementary school by using design One-Shot Case Study, a group of students is given the treatment which one teams is not given a treatment, and Test results will be observed. Design One-Shot Case Study This is described as follows (Figure 3). Main field trials using one group pretestposttest design. The main field test will take place in fifth grade Karang Mekar 1 elementari school Banjarmasin with number of students is 24 persons involved. This design can be described as follows (Figure 4).
The trials of field operations were used in three schools which are two for experiment class (EC). Karang Mekar 1 elementary school and Pengambangan 6 elementary school and one school for control class (CC), Pangeran 2 elementary school Banjarmasin. Those three schools were randomly selected based on regional samples. the operational trial uses the method of research the quast experiment with the monequivalent control group design. In monequivalent control group design, Experimental groups and control groups are chosen at random. Desain monequivalent control group design almost the same as pretest-posttest control group design Which can be modified in the following (Figure 5).

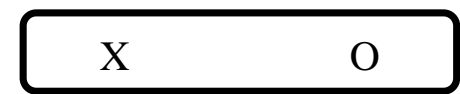

$\mathrm{X}=$ Treatment is studying uses a textbook

$\mathrm{O}=$ Analysis results after treatment through the score of the posttest

Figure 3 One-Shot Case Study Design (Sugiyono, 2010)

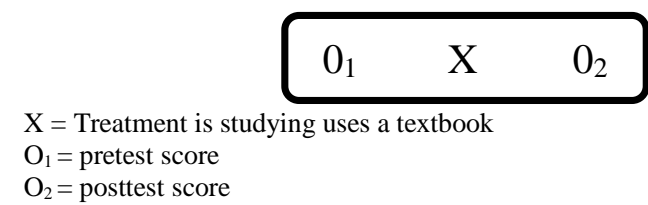

Figure 4 One-group pretest-posttest Design (Sugiyono, 2010)

\begin{tabular}{|l|l|}
\hline Experiment class & Pretest Treatment Posttest $O_{1} X_{1} O_{2}$ \\
\hline Control class & Pretest treatment posttest $O_{3} X_{2} O_{4}$ \\
\hline
\end{tabular}

$\mathrm{O}_{1}=$ The initial aptitude test of an experiment class

$\mathrm{O}_{2}=$ Final test the ability of the experiment class

$\mathrm{X}_{1}=$ Learning using teaching material the results of development

$\mathrm{X}_{2}=$ Learning using plain text teaching materials

$\mathrm{O}_{3}=$ An early control class test

$\mathrm{O}_{4}=$ Final control class test

Figure 5 Nonequivalent Control Group Design (Sugiyono, 2010)

The test subjects in this research and development used validator's test: one material expert and a medium and one doctored book; Early field trials: 6 students fifth grade Karang Mekar 1 elementary school; Main field test : 24 students on fifth grade Karang Mekar 1 elementary school and the field operations test involves three elementary schools, there are Pengambangan 6 elementary school have been 25 students, and Pangeran 2 have 25 students. 
The data obtained on this research and development is quantitative and qualitative data. The quantitative data is the quantitative scores of materials experts, media expert, and dook designer's expert, the pretest and posttest data, and questionnaires' and teachers' response scores (Table 1). Qualitative data is the data obtained from responses on the subject of learning, materials, media, the multi-resource design of materials experts, media experts, book design experts, teachers, and learners.
By adapting intervals to tables, the item of assessment will find minimum scores and maximum scores, then determining $\mathrm{Xi}$ and Sbi values so as to obtain interval criteria for each category. In this study, there are defined as a minimum "B" category "Good" product that development products should be used. If the results of the data analysis do not meet the "Good" category, they will be considered for revision before they are tested.

Table 1 Quantitative to Qualitative Data Conversion

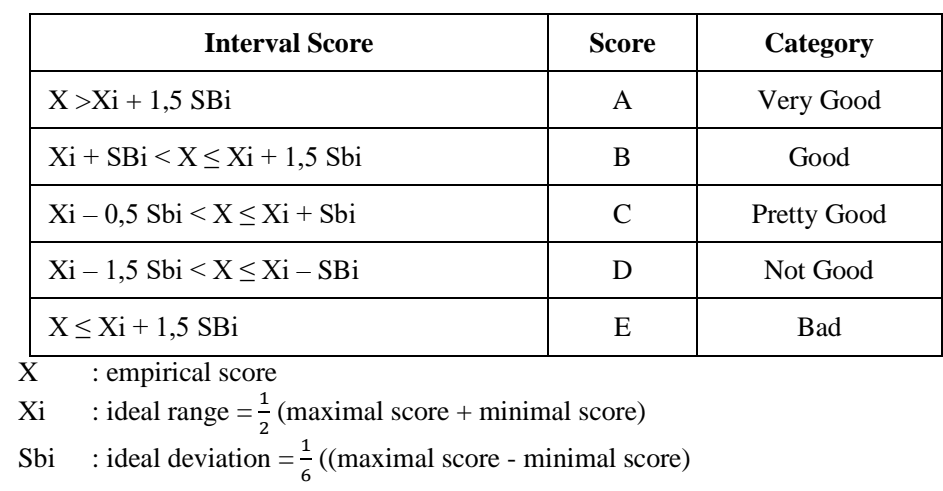

\section{RESULTS AND DISCUSSION}

The results of first product research and development are generally research done at the initial product divided into three stages of data collection, planning and development of product drafts. The result of the exposition of each stage is as follows.

\subsection{Research and Data Collection}

Data collection begins by conducting interviews with teachers and principals. In an effort to strengthen the results obtained through interviews and questionnaires, class teacher and fifth-grade students on perceptions of critical thinking and creative thinking skills. The interview subject suggested that until now they had not figured out the details of what these skills were, how to observe their development and how to evaluate them.

Add to this a lack of knowledge about the indicator of attainment of these three skills as the basis for developing learning strategies. "It is absolutely essential to introduce critical thinking skills, creative thinking skills, and logical thinking skills to teachers, so as to include custom-oriented teaching activities. If necessary, teach materials already contain components of critical and creative thinking" (source: interview, April 13, 2019).

The spread of the questionnaire is done to determine the perceptions of the principal, teachers, and students to critical and creative thinking skills. There are three statements indicators found in the questionnaire and teacher: the perceptions of the principal and the teacher of student activity in critical and creative thinking skills; A teacher's perception of lessons is critical thinking and creative thinking skills and a teacher's perception of a teacher's critical thinking and creative thinking skills. This indicator is set out in 25 questions.

For the student's questionnaire are three statement indicators: the student's perception of critical thinking and creative thinking skills; A student's perception of critical thinking and creative thinking skills and a student's perception of critical thinking and creative thinking skills. This indicator is framed into 25 questions. The results obtained from the conversion of all perception questionnaires distributed are as follows (Table 2).

From the table above we can explain that the score obtained from the teacher's questionnaire was 28 , after conversion it turned out the predicate was "enough". The student questionnaires result got scored 400 predicate scores and the predicate was quite good (Table 3). Based on critical thinking skills and creative thinking skills gets in the category "enough".

This suggests that teachers are expecting books that are highly charged with critical thinking and creative thinking skills knowledge that are practical. This result would complement the interview of the teacher as an analysis of teaching materials for critical thinking and creative thinking skills. Here's a summary of the students' questionnaire (Table 4).

Based on such results, it can be concluded that students' perceptions of critical thinking skills and creative thinking skills get in the categor" enough". This result would be supplemented by the analysis of educational needs to develop material learning critical and creative thinking skills. 
Table 2 The Results from the Teacher and Student Questionnaires

\begin{tabular}{|c|l|c|c|c|}
\hline No & \multicolumn{1}{|c|}{ Questionnaires } & Score Interval & Score & Category \\
\hline 1 & Teacher & 28 & C & Medium \\
\hline 2 & Students & 400 & C & Medium \\
\hline
\end{tabular}

Table 3 Recapitulation of the Teacher's Questionnaire

\begin{tabular}{|c|l|c|c|c|}
\hline No & \multicolumn{1}{|c|}{ Indicator } & Score & Predicate & Category \\
\hline 1 & $\begin{array}{l}\text { The headmaster and teachers' perceptions of student activity in the cultivation of critical, } \\
\text { creative, and logical thinking skills. }\end{array}$ & 9 & C & Medium \\
\hline 2 & A teacher's perception of critical and creative thinking skills. & 13 & C & Medium \\
\hline 3 & Teachers' perceptions of learning textbooks that contain critical and creativeal thinking skills. & 6 & C & Medium \\
\hline
\end{tabular}

Tabel 4 Students Questionnaire Result Recapitulation

\begin{tabular}{|c|l|c|c|c|}
\hline No & \multicolumn{1}{|c|}{ Indicator } & Score & Predicate & Category \\
\hline 1 & Students' perception of critical thinking and creative thinking skills. & 209 & C & Medium \\
\hline 2 & A student's perception of learning is critical thinking skills and creative. & 97 & C & Medium \\
\hline 3 & Students' perceptions of the textbook are critical thinking skills and creative. & 94 & C & Medium \\
\hline
\end{tabular}

\subsection{Preparation of Teaching Materials that Are}

\section{Critical and Creativeal Thinking Skills}

\subsubsection{The Preparatory Stage}

This stage contains a heading to learning, this activity contains explanations that can be used for both teachers and students in preparing what will be found in the learning process. Here is an example of the preparation section on textbook (Figure 6).

\subsubsection{Activities that Contain Critical Thinking}

\section{Skills}

In this activity, students are invited to observe and absorb information in a text that is equipped with various data and realities in everyday life. In this section, students will reveal various facts associated with the experiences of their daily lives.

Students are asked to apply what is in the teaching material to their daily lives and to dig at what problems are available in information and to dig at solutions to the problems. In other words, this critical thinking skill consists of extracting information by locating veracity or facts, producing interpretation, analysis, evaluation, and inference, as well as exposure using evidence and setting the best criteria for making decisions (Figure 7).

\subsubsection{Activities that Contain Creative Thinking} Skills

The thought activity contains the ability of the student to give a number of different ideas or ideas by using the imagination based on rational concepts (Figure 8).

\subsection{Expert Assessment}

Before the product is piloted, this textbook was first evaluated and validated by materials experts, media experts, and book design specialists. The validation is carried out to determine the propriety of teaching materials. Teaching materials can be tested when expertly deemed feasible by experts. Based on media experts, the design of the text receives several notes of which the front should be improved illustrations and texts, the back cover for the design to be refined and unpacked with too much design, the colorability of books should be consistent and tendency to make the reader feel comfortable, the font size should not be too small.

The material expert assessment contains an appraisal of the content worthiness and presentation in the textbook material. This assessment results are data in the form of a master material instrument that has been developed. The expert Prof. Drs. Ahmad Suriansyah, M.Pd., Ph.D., an education expert in south Borneo, who has become a principal South Kalimantan education accreditation, he has a comprehensive mastery over the design for the basic school teaching and material development tool. Here are pictures of material assessment results taught by materials experts (Figure 9). 


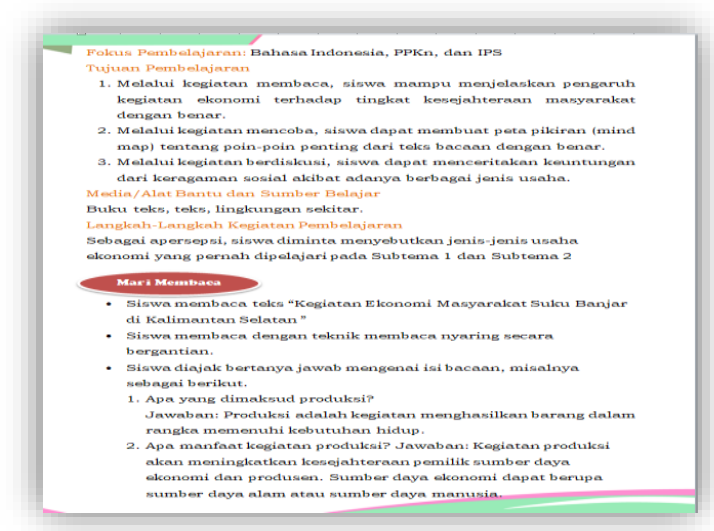

Figure 6 Example of Preparation Section

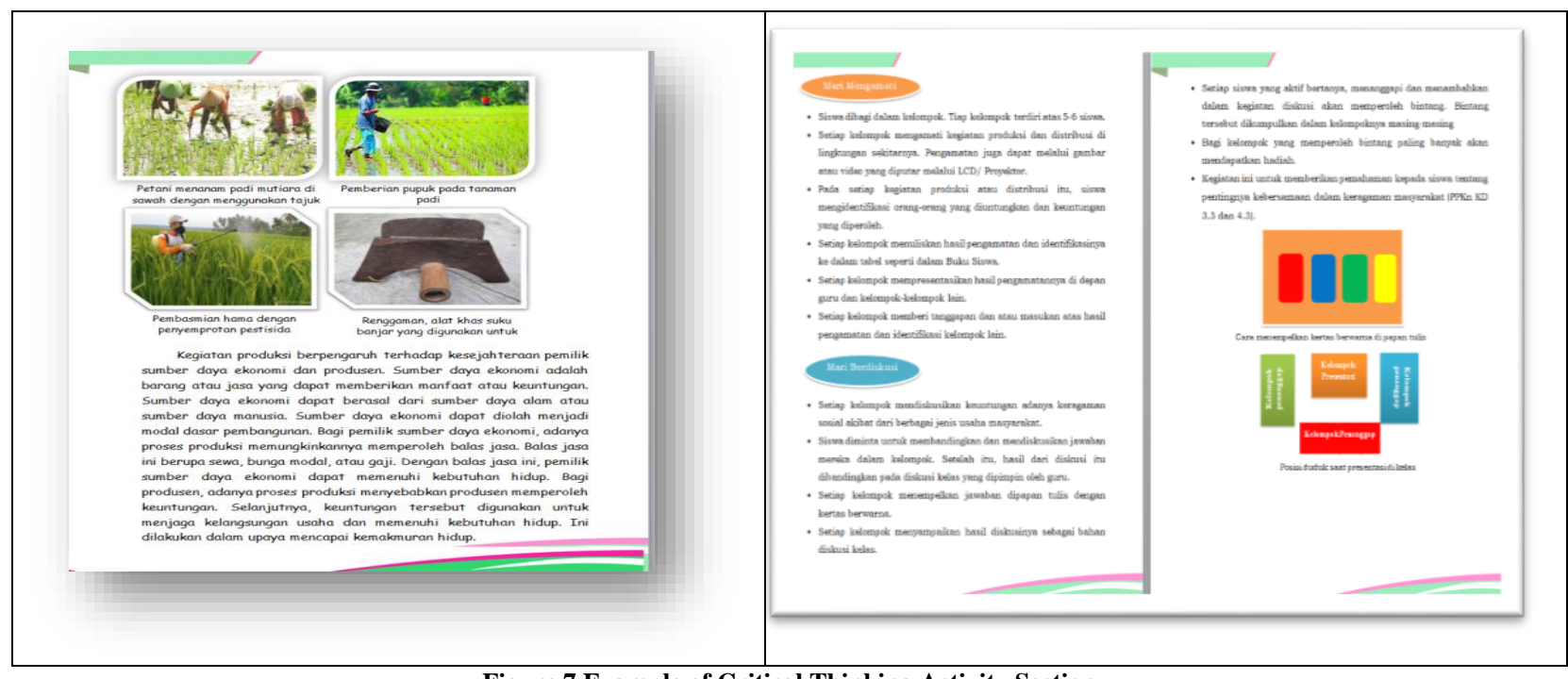

Figure 7 Example of Critical Thinking Activity Section

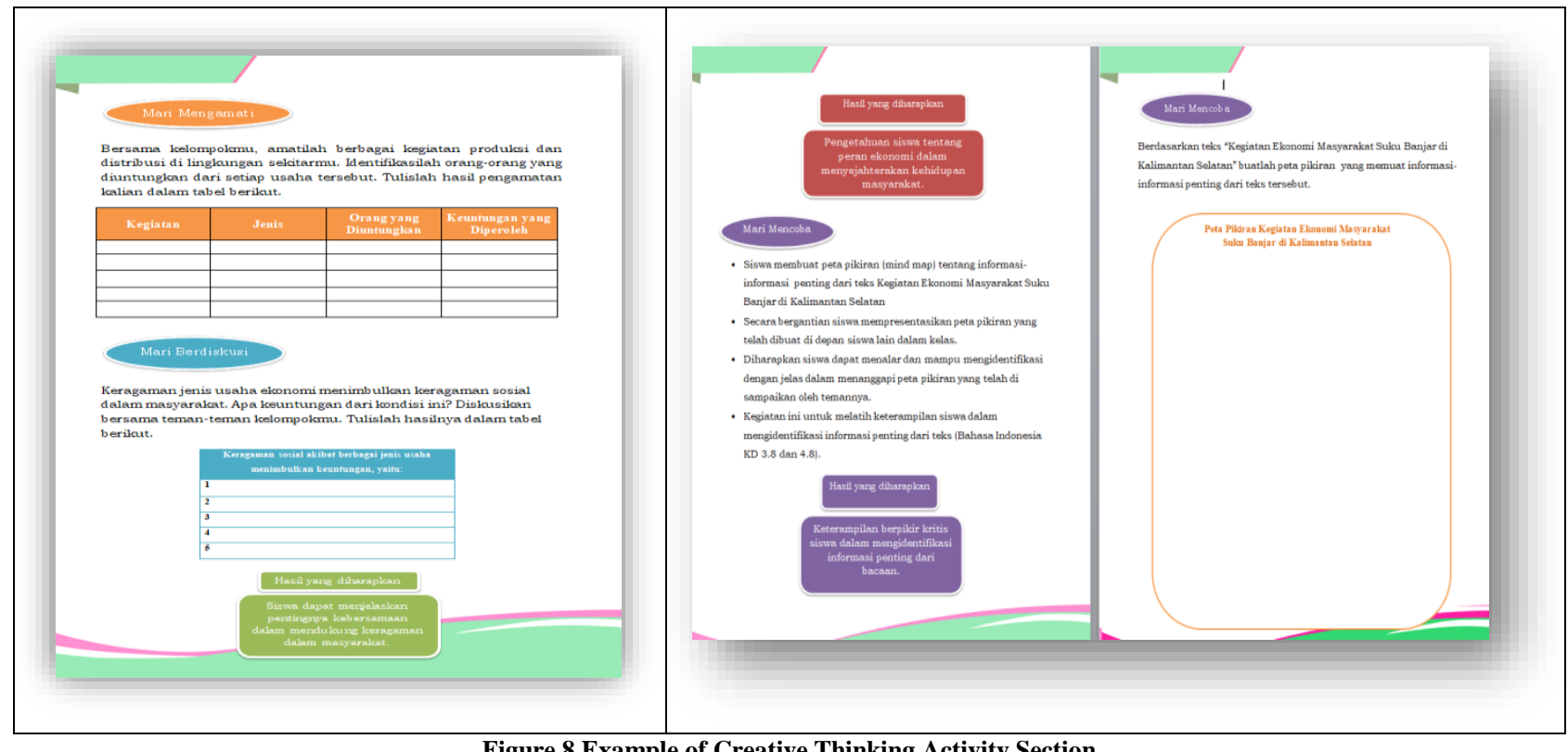

Figure 8 Example of Creative Thinking Activity Section 


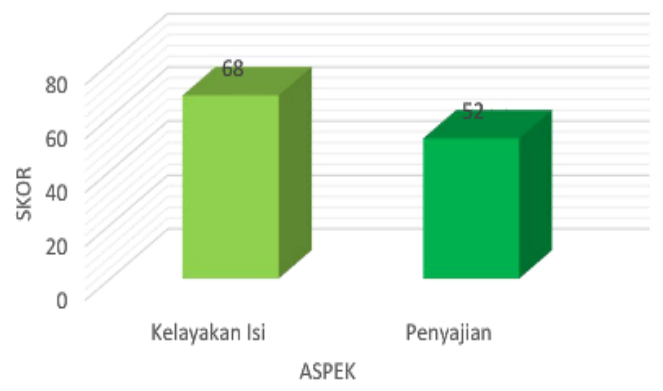

Figure 9 Learning Materials Content Appropriateness Assessment Result

Based on figure above, the material product assessment by materials experts scored 120 . These scores when they converge get good ratings. Thus, the teaching material developed will be 68 for each aspect of worthiness, both good category and 52, for category good presentation aspects. A material master's assessment contains an assessment of language and commonality with materials. This assessment results data in the form of a medical-skill sheet have been developed. The evaluation of teaching products from the media aspect of the media will be scored converging onto a scale of five. The following are images of valuing materials by media experts (Figure 10).

\section{Skor Penilaian Ahli Media}

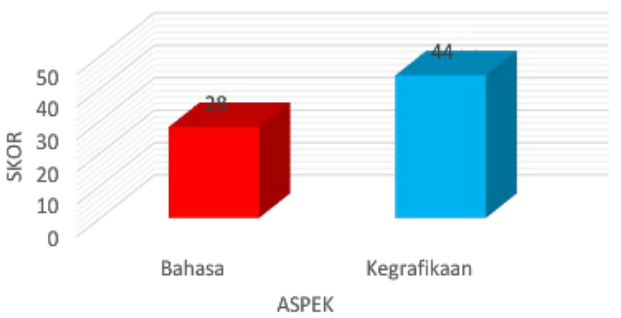

Figure 10 Learning Materials Media Appropriateness Assessment Result

Based on the above images, the grading of materials by media experts scores 72 . These scores when they converge get good ratings. Thus, the teaching material developed is said to be worthy of the score of each aspect 28 for both category languages and 44 for areas worthy of praise. A book design expert assessment contains an assessment of overall design forms, the anatomy of the contents of books and the anatomy of a book cover on teaching materials. This material expert assessment data consists of a master tool that has been developed. The valuation of educational products from the design aspect of the book's scores are converging onto a scale of five. Here are the drawings of the materials assessments by a book designer (Figure 11).

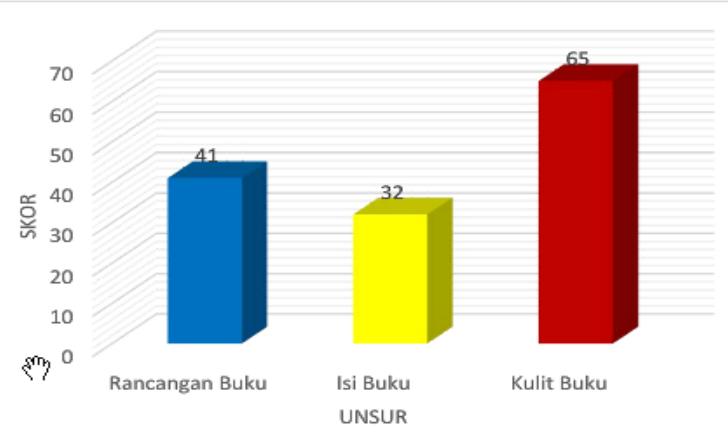

Figure 11 Learning Materials Design Appropriateness Assessment Result

Based on the above figure, the valuation of materials taught by book design experts gets 138 . These scores when they converge get good ratings. Thus, the teaching material developed is worthy of the score of each aspect of the design is 41 to the design aspect of a good category book, 32 for the content of a good book and 65 for the cover of a book get good category.

\subsection{Product Test Results}

Early field trials will take place in 5th-grade SDN Karang Mekar 1 of over a two-week period with a subject of 6 students. Early field trials were done to establish evidence of the feasibility of a local textbook containing local wisdom for developing critical thinking and creative thinking skills. In these early field trials, the administration was aided by one observer because it was difficult for researchers to do their own research. Observers are assisting with the study activity documentation. The grades taken in an early field test are critical thinking and creative thinking skills at the end of learning or posttest. And that was because it was a pre-field test using the design of the one-shot case study. Posted performed after the initial field test was completed. The problem presented with the dual choice and the essay choice problem. Here is the data of critical thinking and creative thinking skills test after taking part in a study with a local collective containing local wisdom (Table 5).

Table 5 Preliminary Field Test Results

\begin{tabular}{|c|c|c|c|}
\hline No & Subject & Score & $\begin{array}{c}\text { Category } \\
\text { (Min. Score 65) }\end{array}$ \\
\hline 1. & AAT & 68 & Complete \\
\hline 2. & SNS & 68 & Complete \\
\hline 3. & DS & 80 & Complete \\
\hline 4. & MR & 73 & Complete \\
\hline 5. & WAC & 76 & Complete \\
\hline 6. & AR & 70 & Complete \\
\hline
\end{tabular}

Based on the table above it is known that students' highest scores were obtained on test subjects using initiative with 80 and lowest scores earned by current subjects and SNS using is 68. The test subject is said to be completed because it has reached a designated minimum 
completeness criterion that is 65 . The average of learning value while testing the initial field is 72.5 . Based on such results, thematic textbooks containing local wisdom for developing critical and creative thinking skills are deemed viable and thus a thematic textbook can be used for a major field test.

\subsection{Test Results from the Main Field}

The main field test took place in the fifth-grade SDN Karang Mekar 1 over a two-week period with a test subject of 24 students. The aim of a key field test is to implement revised products after an early field test and to learn the effectiveness of local collectives containing local wisdom through critical and creative thinking skills tests. The results of the test are pretest and posttest scores of 24 students. And that's because it's in the field trials using one group posttest design. The problems presented are multiple-choice and essay choices.

The pretest was done before students used thematic textbooks with content local wisdom. While posttests are done after conducting the main field test. Below is the data of critical thinking and creative thinking skills test data major field test before and after taking a study using local wisdom that developed critical and creative thinking skills (Table 6).

Table 6 Critical Thinking Skills and Critical Field Test Results

\begin{tabular}{|c|c|c|c|c|c|c|}
\hline No & Subject & Pr & $\mathbf{P t}$ & Subject & Pr & $\overline{P t}$ \\
\hline 1 & Msk & 60 & 66 & EA & 40 & 60 \\
\hline 2 & Msy & 60 & 80 & Swn & 50 & 62 \\
\hline 3 & WRR & 73 & 87 & RS & 58 & 75 \\
\hline 4 & AAT & 68 & 76 & MR & 72 & 78 \\
\hline 5 & SNS & 66 & 83 & Art & 55 & 75 \\
\hline 6 & $\mathrm{DF}$ & 22 & 60 & WAC & 78 & 87 \\
\hline 7 & DS & 80 & 93 & AR & 70 & 76 \\
\hline 8 & $\mathrm{AP}$ & 40 & 90 & JA & 70 & 83 \\
\hline 9 & ST & 48 & 70 & MNH & 52 & 70 \\
\hline 10 & Wrn & 55 & 92 & DA & 60 & 90 \\
\hline 11 & $\mathrm{Fbt}$ & 42 & 87 & MM & 55 & 75 \\
\hline 12 & TALP & 38 & 58 & KK & 75 & 95 \\
\hline \multicolumn{2}{|r|}{ Count } & 1.387 & 1.868 & & & \\
\hline \multicolumn{2}{|r|}{ Range } & 57,8 & 77,83 & & & \\
\hline \multicolumn{2}{|c|}{ Gain Score } & \multicolumn{2}{|c|}{0,47} & & & \\
\hline
\end{tabular}

Pr: Pretest

Pt: Posttest

Based on the table above, it can be explained that the results of the pretest main field test followed by 24 students. The highest score is 80 and the lowest score is 22 . And the pretest results performed by the student are 15 students who did not reach the minimum completeness criteria. The predetermined minimum completeness criteria are 65. Posttests are given after students carry out the learning activities using local wisdom based thematic textbooks. Posttest data indicate that there are 4 students who did not reach the $\mathrm{km}$. Posttest high is 95 , and for the lowest scores is 58 .

\subsection{Results of a Field Operational Test}

The results of field operations test took place at SDN Karang Mekar 1, SDN Pengambangan 6, and SDN Pangeran 2. As a class on experimentation SDN Karang Mekar 1 With the test subjects of 20 students and SDN Pengambangan 6 with the test subjects 25 students. As for the control class SDN Pangeran 2 with a test subject of 25 students. The trials of field operations are conducted for eight sessions. The purpose of field operations trials is to implement revised products on previous trials and to test the effectiveness of textbook's critical and creativeal process-based approaches in improving critical thinking and creative student skills. The data at the field operational trials included the results of critical thinking and creative think skills test through the students' and teacher response questionnaments.

Analysis from field operational data is done to determine the effectiveness of textbooks that were developed in improving critical and creative thinking skills. Critical thinking and creative thinking skills are good when students are able to master the competence set out for the purpose of learning. One of the doctrinal mastery competencies is the value students obtain compared to minimum completeness criteria. Individuals are said to be complete when they obtain a minimum of 65 learning value while classifying learning is said to be complete if at least $75 \%$ of the students have studied or scored a minimum of 65 .

The effectiveness of students' study results is seen by evaluations of critical thinking and early-creative thinking skills test or critical thinking and final creative or posttest. The pretest data is the obtained data to determine a student's initial ability. The data obtained are test results in experiment classes and control classes. In an experiment class, the test is done before carrying out critical thinking and creative learning activities using highly developed textbooks, while the control test class does before carrying on the normal critical and creative thinking activity. Posttest data is the data obtained after students carry out critical thinking and creative learning activities, either those using a local proficiency textbook or those not using or using a textbook used by teachers in the classroom.

The number of students for the experiment class (ke) total of 45 while the students for the control class (kk) total 25 . The process of critical thinking and creative study in an experiment class uses a highly charged local wisdom textbook that develops critical thinking and creative thinking skills, whereas the learning process used by teachers. The following is an explanation of the results of studying in experimental and controlled classes in the field trials:

The results of studying in an experiment class are taken from 25 students of the 5th grade SDN Karang Mekar 1 and 5th-grade SDN Pengambangan 6 Banjarmasin. Data is obtained from critical thinking and creative thinking skills performed on students before performing the learning activities and from critical and creative thinking 
skills that are performed on students after carrying out a posttest using local college-containing thematic textbooks to develop critical and creative thinking skills. The following are the results of the test and posttest students for the experimental class (Table 7).

Table 7 Pretest and Posttest Result from Experiment Class

\begin{tabular}{|c|c|c|c|}
\hline No & Subject & $\begin{array}{l}\text { Pretest } \\
\text { Score }\end{array}$ & $\begin{array}{c}\text { Posttest } \\
\text { Score }\end{array}$ \\
\hline 1 & SSR & 52 & 72 \\
\hline 2 & DS & 55 & 80 \\
\hline 3 & Ryd & 66 & 78 \\
\hline 4 & DD & 30 & 55 \\
\hline 5 & IA & 55 & 66 \\
\hline 6 & $\mathrm{AP}$ & 80 & 90 \\
\hline 7 & RWB & 72 & 83 \\
\hline 8 & DD & 28 & 43 \\
\hline 9 & DA & 60 & 80 \\
\hline 10 & ARA & 58 & 78 \\
\hline 11 & RIA & 30 & 43 \\
\hline 12 & RSP & 75 & 95 \\
\hline 13 & RRT & 72 & 80 \\
\hline 14 & $\mathrm{MRH}$ & 47 & 62 \\
\hline 15 & $\mathrm{RH}$ & 50 & 75 \\
\hline 16 & MSF & 45 & 66 \\
\hline 17 & $\mathrm{AA}$ & 50 & 78 \\
\hline 18 & AWD & 66 & 80 \\
\hline 19 & MNZ & 55 & 72 \\
\hline 20 & ARH & 58 & 80 \\
\hline 21 & MA & 55 & 70 \\
\hline 22 & RHY & 60 & 65 \\
\hline 23 & RIA & 52 & 70 \\
\hline 24 & $\mathrm{ABZ}$ & 60 & 68 \\
\hline 25 & AGR & 66 & 73 \\
\hline
\end{tabular}

In the posttests of the 25 students, the highest score the student got was 95 , and the lowest score was 43 . There are 6 students who do not achieve the minimum standard of 65 but classify $86.6 \%$ students at the minimum completeness criteria. Average student posttest score is $73.9 \%$ by the standard deviation of 10,49 . While the study results for control classes were taken from 25 students of SDN Pangeran 2. The data comes from critical and creative thinking skills tests before critical and creative thought skills and critical and creative thinking skills after carrying out critical and creative thought activities. In the control class, the textbook used is the textbook teachers use as usual when they're in English. The results of the test and posttest students obtained at control class can be seen at the following Table 8 .

The results show that the highest-grade students received in control during the exam class is 78 and the lowest score is 50. In control, there are 9 students who haven't reached the minimum criteria for accuracy, which is 65 . The average student learning result is 65.72 by a standard deviation of 8.26. The highest grade the student received at the posttest was 80 and the lowest score was 38 . There are 6 students who have not been completed at 65 , but $76 \%$ of students are classified. The average student posttest score is 67.76 by the standard deviation of 11.01 .
Table 8 Pretest and Posttest Result from Control Class

\begin{tabular}{|c|c|c|c|}
\hline No & Subject & Pretest Score & Posttest Score \\
\hline 1 & ASP & 78 & 78 \\
\hline 2 & RM & 70 & 72 \\
\hline 3 & AL & 70 & 70 \\
\hline 4 & ALA & 72 & 78 \\
\hline 5 & AG & 50 & 38 \\
\hline 6 & ARI & 60 & 63 \\
\hline 7 & RSP & 78 & 80 \\
\hline 8 & RRT & 66 & 66 \\
\hline 9 & MRH & 60 & 72 \\
\hline 10 & RH & 58 & 72 \\
\hline 11 & MSF & 78 & 80 \\
\hline 12 & AA & 50 & 43 \\
\hline 13 & AWD & 72 & 75 \\
\hline 14 & MNZ & 78 & 78 \\
\hline 15 & ARH & 55 & 48 \\
\hline 16 & MA & 66 & 72 \\
\hline 17 & RHY & 70 & 72 \\
\hline 18 & RIA & 70 & 66 \\
\hline 19 & ABZ & 60 & 60 \\
\hline 20 & AGR & 60 & 66 \\
\hline 21 & AKR & 66 & 60 \\
\hline 22 & ACP & 60 & 70 \\
\hline 23 & PRT & 60 & 66 \\
\hline 24 & SD & 66 & 70 \\
\hline 25 & SG & & 70 \\
\hline
\end{tabular}

To determine the effectiveness of textbooks in improving critical thinking and creative thinking skills at field practice can be seen in the attainment of student study results and the difference in the effectiveness of textbooks that are used in experiment and control classes. To figure out the range of results of critical thinking and creative thought in experiment and control classes used test results. In this study the independent calculations of sample tests using the SPSS CPU programs at 16.0. Before doing this test, analysis prerequisite tests, which are normality and homogeneity. The following are the analysis of normality tests and homogeneity tests. Normality data assessment enabled by using the SPSS 16.0 (statistical product and services solutions). Normality testing is based on the following hypothesis:

$\mathrm{H}_{0}$ : The samples came from a normal-distributed population

$\mathrm{H}_{1}$ : The sample doesn't come from a normal distributed population

H0 Rejected when significance is less than $(\mathrm{a}=$ $0.05)$. On the other hand, if its significance is greater then its normality and homogeneity are met. The following are the results of the normality test scores of the test and the student posttest (Table 9). Based on the data shown on the top Table 9 of normality test results, it is transcended that normality results with significant value are greater than the probability of 0.05 . Thus, h0 is received or the data is distributed normally. While data's normality test as a prerequisite test, there are also data homogeneity tests. The test of homogeneity is intended to sample what was used as a subject for research to be homogeneous or nonhomogeneous. 
Table 9 Normality Test Summary

\begin{tabular}{|l|c|c|c|}
\hline \multicolumn{1}{|c|}{ Test } & N & Kolmogorov-Smirnov & Significant \\
\hline Pretest (KE) & 45 & 1,064 & 0,208 \\
\hline Posttest (KE) & 45 & 1,235 & 0,094 \\
\hline Pretest (KK) & 25 & 0,778 & 0,580 \\
\hline Posttest (KK) & 25 & 0,983 & 0,289 \\
\hline
\end{tabular}

To need to find a homogeneous variant of the population, based on the following hypothesis.

H1 : The variety of population test results of learning results between the respondents in control and experiment classes is different (not homogeneous). If the probability of the bag > 0.05 , then the h0 was accepted to be the same variant, reverse if the probability <_ 0.05 , then the h0 was rejected to be a different variant.

Based on the Table 10, it is said that the test of homogeneity with its value results is greater than the probability of 0.05 . So, it could be transmitted or the data is homogeneous. The difference in the improvement of study results in experiment and control classes based on normality and data homogeneity is concluded that data distributed normally and homogeneous to figure out the difference in the results of the study in experiment and control classes is a test run. Independent calculations sample t-test using the SPSS program 16.0. The developed textbook product is only effective if the results of the posttest of the experiment class are better than those of control. Here is a hypothetical test:

$\mathrm{HO}$ : There is no significant difference between the results of the experimental posttest class and those of the post-test class control.

H1 : There is a significant difference between the results of the experimental posttest class and the post-test class control.

\section{Decision Criteria:}

If $\operatorname{sig}<$ a significant

If sig $>$ a insignificant

The criteria for acceptance or rejection of $\mathrm{h} 0$ significant level $5 \%$ by significance, which is when significance is significant $>0.05$ hence $\mathrm{h} 0$ is acceptable, as the significance of $<0.05$ is null. The following are the independent calculations of posttest test results from experiment classes and control classes using SPSS 16.0 for Windows (Table 11).

Based on the table above, it should be seen that the average posttest student experiment with the number of 45.93 students is 73.93 by the standard deviation of 10.49 while the student control with the number of students of 25 is 67.76 by a standard deviation of 11.01 . That mean, the average value posttest that students obtain, that average posttest value differs between an experiment class and a control class, which is that the average posttest test test test is higher than the average posttest class control. To see the difference in the results is significant (statistically evident), it must look out for the second part of independent dating sample test results for posttest test results, experiment class and control classes using an SPSS 16.0 for Windows that follows (Table 12).

While homogeneity tests induced homogeneous variance, therefore creativeal different-test should exercise equal variance assumptions. From output SPSS on the table is looks like the value of $t$ at the equal variance measurement is 2.317 and df 68 with a synchronized 0.05 . If the significant value result $<05$ then $h$ stranded was rejected and h1 received or the result of the experimental class posttest is better than the posttest control class point of significance. All right. Sig retailed. That's an.024. Average posttest experimental class $(73,9333)$ is greater than the control class post (67.7600). Based on these results, it can be concluded that there is a significant difference between the results of the experimental class posttest and the control class posttest.

The students' initial skills in both classes are a little different. Average the test grade of the test is slightly lower than the test test test class. When examined, the average of the test scores of a lower experiment class is caused by some students who score very low compared to the control class. Across the posttest value, the experimental class obtained higher values than the average control class. This is because the value of the experiment class is experiencing a quite significant increase compared to the control class. In other words, using a rheumatic textbook can have a positive effect on a student's learning that can improve critical thinking and creative thinking skills in a studen.

Pre-test results, reviewed from pretest and posttest scores. In an experimental whole learning process using students actively engaging in learning activities. It measures up to the step the model of learning that is developed to improve critical thinking and creative thinking skills. Through that stage - that stage students can improve thinking skills. Textbooks are also equipped with problems -- exercises that can strengthen a student's understanding of literature. With problems -- exercises that allow students to be trained in solving problems -problems based on a high level of skill that means that the students' grades in an experiment class are higher than the control class.

It might also be said that the thematic learning process of an experiment class uses a local collectible of wisdom to develop critical thinking and creative thinking skills more effectively improving a student's thinking skills than a control class that does not use the textbook. 
Table 10 Summary of the Results of the Homogeneity Test

\begin{tabular}{|l|c|c|c|}
\hline \multicolumn{1}{|c|}{ Test } & N & Levene Statistic & Significant \\
\hline Pretest and Posttest Experiment Class & 90 & 0,451 & 0,504 \\
\hline Pretest and Posttest Control Class & 90 & 0,658 & 0,421 \\
\hline
\end{tabular}

Table 11 Different Posttest Experimental Class and Statistical Group Control Class

\begin{tabular}{|l|c|c|c|c|}
\hline \multicolumn{1}{|c|}{ Class } & N & Mean & Std. Deviation & Std. Error Mean \\
\hline Experiment & 45 & 73.9333 & 10.49329 & 1.56425 \\
\hline Control & 25 & 67.7600 & 11.01998 & 2.20400 \\
\hline
\end{tabular}

Table 12 Independent Sample Test from Experiment and Control Class

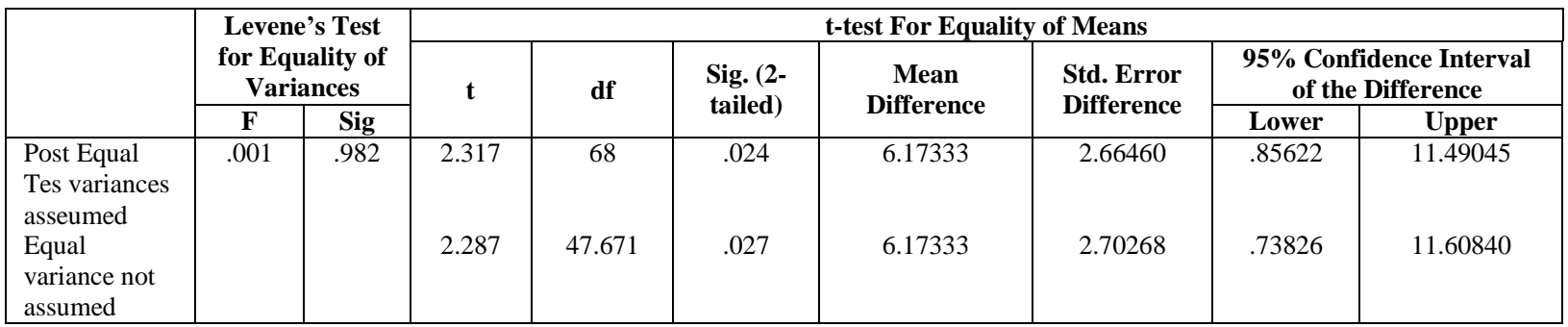

\subsection{The Teacher's and Student Response Questioners' Result}

The spread of the questionnaire is done to know the teacher's and students' responses to a critical and creativeal pathic-based approach process that developed. Teacher responders 10 people made up of principal and school teachers involved SDN Pangeran 2 Banjarmasin county, SDN Pengambangan 6 and SDN Karang Mekar 1 Banjarmasin. As for the 24 student responders taken from the entire fifth class of SDN Pengambangan 6 and SDN Pangeran 2 Banjarmasin.

There are three statement indicators found in the teacher's responses to the textbooks' critical and creativeal based process approach: responses to the content of the book. As for the student's response questionnaire to the local shrewdness for developing critical and creative thinking skills are four statements indicators: the student's response to presentation, the student's response to material or content, the student's response to presentation, the student's response to language, and the student's response to literacy. The indicator was described to 15 questions.

Based on the results of the teacher's response and student's response questionnaires can be concluded that a teacher's response to a local wisdom-charged thematic textbook to develop critical and creative thinking skills and a student's response to a local medically charged textbook to develop critical and creative thinking skills is excellent. The teacher and student response questionnaire are the following (Table 13).

From the Table 13, you can explain that the total score for the teacher's results is: get 149 and that is consistent with the above table where the predicate is a very good category a. From the student response questionnaire that is to get 636 and the score corresponds to table 27 , the predicate is a very good category. Thus, a thematic textbook containing local wisdom for developing critical thinking and creative thinking skills is particularly useful.

Besides, the teacher's response data is obtained from the questionnaire. The teacher's response questionnaire came up with the data that local wisdom containing thematic textbooks to develop critical thinking and creativeal grade $\mathrm{v}$ skills received a good response from the users of the teacher. The questionnaires' scores have conversed to a scale of five as shown in the next Table 14.

Based on the table it can be explained that a teacher's response to a local collegiate thematic textbook to develop critical and creative thinking skills scored a total of 149. From that score, if it's concentrated, you get a very good category a predicate. As for scores for each - each indicator is: the design of the book scores 80 in a very good category, the skin of the book scores 30 in a very good category, and the contents of the book score 39 in a very good category.

Based on the table it can be explained that a teacher's response to a local collegiate thematic textbook to develop critical and creative thinking skills scored a total of 149. From that score, if it's concentrated, you get a very good category a predicate. As for scores for each - each indicator is: the design of the book scores 80 in a very good category, the skin of the book scores 30 in a very good category, and the contents of the book score 39 in a very good category (Table 15).

Based on the table it can be explained that a student's response to a local thematic textbook containing local wisdom to develop critical thinking and creative thinking skills scored 636. From that score, if it's concentrated, you get a very good category a predicate. As for the individual scoring scores -- each indicator is: the material or the content gets 177 in a very good category, the language scores 127 in the very good category, and the grain scores 130 in a very good category. 
Table 13 The Teacher and Student Response Results

\begin{tabular}{|c|l|c|c|c|}
\hline No & Questionnaire & Score & Result & Category \\
\hline 1 & Teacher Response & 149 & A & Very Good \\
\hline 2 & Students Response & 636 & A & Very Good \\
\hline
\end{tabular}

Tabel 14 Summary of Teacher Response Questionnaire Results

\begin{tabular}{|c|l|c|c|c|}
\hline No & \multicolumn{1}{|c|}{ Indicator } & Score & Result & Category \\
\hline 1 & Textbook Design & 80 & A & Very Good \\
\hline 2 & Cover & 30 & A & Very Good \\
\hline 3 & Content & 39 & A & Very Good \\
\hline
\end{tabular}

Table 15 Summary of the Student's Response Questionnaires

\begin{tabular}{|c|l|c|c|c|}
\hline No & \multicolumn{1}{|c|}{ Indicator } & Score & Result & Category \\
\hline 1 & Content & 202 & A & Very Good \\
\hline 2 & Presentation & 177 & A & Very Good \\
\hline 3 & Language & 127 & A & Very Good \\
\hline 4 & Graphic & 130 & A & Very Good \\
\hline
\end{tabular}

\subsection{Product Revision}

Revision of a thematic textbook product containing local wisdom to develop critical and creative thinking skills based on validator's Suggestions, teachers, and associates.

\subsubsection{First Product Revision}

Draft revision was done on validator 's advice,' This revision was done after the validation of locally produced thematic text products to develop critical and creative thinking skills. Here is a section -- a section of a thematic text that needs revision according to validator's suggestions: (1) there need to be consistent colors and standards similar in the layout of the title, subheadings, page numbers, walking headings, illustrations; (2) title of subthemes need to be magnified a little bit; (3) the layout of the logo and text on the face of the textbook needs to be repaired; (4) the size of the text headings of the textbook on the back of the book needs to be trimmed; (5) this synopsis decoration of textbooks on the back should be removed; and (6) early revised draft products are used for preliminary field trials.

\subsubsection{Second Product Revision}

Second product revision is done on teacher advice. This revision came after the initial field test run. Some of these revised things include the following: (1) maintenance on some workout issues; and (2) improvements to images and a subtheme opening conversation. An early field test product that had been revised was then used for field trials at SDN Karang Mekar 1 Banjarmasin. This was done as a later stage of development.

\subsubsection{The Third Product Revision}

This third product revision is done on the teacher's advice. This revision came after the primary field test. Revision at this stage, that is: (1) sentence repair with the section "introduction" last sentence in paragraph two; and (2) improvements to the "what is in this book" section shed further light on the contents of the book. A revision main field test product is then used for field operations at SDN Karang Mekar 1 and SDN Pangeran 2 Banjarmasin.

\subsection{Final Product}

The final product of a local collection-containing of local wisdom to develop critical and creative thinking skills is the result of a revision of the initial draft, a revision of the initial field test through a revision of the main field test. The final product is a thematic textbook entitled "our environment of choice: thematic material with critical thinking and creative thinking skills." This textbook is supplementing the thematic teaching material in curriculum 2013 on our friend ward theme. The point of a supplement is that the book that was developed complements the teaching-learning process that was not available in a ministry book that contains step a learning approach that contains elements critical thinking and creative thinking skills.

\section{CONCLUSIONS}

Based on research and development results, it may be concluded that thematic textbooks contain critical thinking skills and standardized creative wisdom for a grade in elementary school $\mathrm{v}$ are organized in accordance with the components of material worthiness, media, and book design. Our friend environment study material presentation subtheme 3 environmental preservation efforts of study 1, 2, 3, 4, 5, 6 presented with the content of local wisdom in the province of South Kalimantan. As for the results of research and development could be detailed as follows.

Thematic textbooks which is containing with critical thinking skills and creative thinking skills based on local wisdom is ready to be used for elementary school on fifth grade. According to materials, however, the thematic text with critical thinking and creative thinking skills scored 120 points, with a predicate B and "good" category. 
Thematic textbooks which is containing with critical thinking and creative thinking skills based on local wisdom is ready to be used for fifth grade elementary school. According to media experts, thematic textbooks containing critical thinking and creative thinking based local wisdom are scored by 72 , with a $\mathrm{B}$ predicate and in the "good" category.

Thematic textbooks which is containing with critical thinking skills and creative thinking based on local wisdom that resulted is effective to use for fifth grade elementary school students. This is all attested to by a sig. (tailed) that is $0.024<0.05$. Thus, $\mathrm{h} \_0$ is rejected and the approved h_1 or the results of the experimental class are better than the posttest control class. The posttest test class experiment $(73,9333)$ is greater than the posttest control class (67.7600). Based on these results, it can be concluded that there is a significant difference between the results of the experimental class posttest and the control posttest scores. Judging by the section of the study results, the average availability of the study results has taken an upswing in the pre-test and posttest scores. The results of the different tests between the control class and the experiment class show that there is a significant difference between the learning results between the control class learners and the study of experimental class learners.

Thematic textbooks which is containing with critical thinking and creative thinking skills based on local wisdom get excellent responses from users, they are teachers and students. This is evidenced by teachers' questionnaire which is get total score 149 with criteria "very good" and from the questionnaire's responses total scored total of 636 with criteria "very good". It means that the textbook is appropriately applied.

\section{REFERENCES}

[1] Agusta, A. R., \& Noorhapizah. (2018, Desember 12). Improving the Student's Cooperation and Environmental Care Skill using Outdoor Learning Strategy Outbound Variation. 1st International Conference on Creativity, Innovation and Technology in Education (IC-CITE 2018) (pp. 10-17), Banjarmasin, Atlantis Press.

[2] Agusta, A. R., Setyosari, P., \& Sa'dijah, C. (2018). Implementasi Strategi Outdoor Learning Variasi Outbound untuk Meningkatkan Kreativitas dan Kerjasama Siswa Sekolah Dasar. Jurnal Pendidikan: Teori, Penelitian, dan Pengembangan, 4(1), 453-459.

[3] Anitah, S. (2010). Strategi Pembelajaran. Modul Bahan Ajar.

[4] Barry, M. (2012). What skills will you need to succeed in the future? Phoenix Forward (online). Tempe, AZ, University of Phoenix.

[5] Fahlivi, M. M., \& Asniwati. (2018). Implementasi Kombinasi Model Jigsaw, Mind Mapping dan Make a Match untuk Meningkatkan Aktivitas Belajar Siswa Kelas $V$ SDN Pengambangan 6 Banjarmasin. Banjarmasin: FKIP Universitas Lambung Mangkurat.

[6] Fauzi, Z. A., \& Fikri, H. (2018). Improving Learning Activities Using a Combination of Mind Mapping Model, Think Pair Share and Teams Game Tournament. 1st
International Conference on Creativity, Innovation and Technology in Education (IC-CITE 2018) (pp. 318-322). Banjarmasin, Atlantis Press.

[7] Gillies, R. M., \& Boyle, M. (2009). Teacher's Reflecations On Cooperative Learning: Issues of Implementation. Teaching and Teacher Education, 26, 1-8.

[8] Goethals, P. L. (2013). The Pursuit of Higher-Order Thinking in the Mathematics Classroom. Retrieved October, 1, 2020, from http://www.westpoint.edu/cfe/Literature/Goethals_13.pdf.

[9] Hasratuddin. (2014). Peningkatan Kemampuan Berpikir KritisMatematis dan Kemandirian Belajar Siswa SMP melalui Pembelajaran Berbasis Masalah. Jurnal Kreano. Retrieved October, 1, 2020, from https://journal.unnes.ac.id/nju/index.php/kreano/article/vie $\mathrm{w} / 3325$.

[10] Hosnan, M. (2016). Pendekatan Saintifik dan Kontekstual dalam Pembelajaran Abad 21 : Kunci Sukses Implementasi Kurikulum 2013. Bogor: Ghalia Indonesia.

[11] Istianah, E. (2013). Meningkatkan Kemampuan Berpikir Kritis dan Kreatif Matematik dengan pendekatan Mode Eleciting Activities (MEAs) pada Siswa SMA. Jurnal Ilmiah Infinity Program Studi Matematika STKIP Siliwangi Bandung, 2(1), 9-17.

[12] Kemendikbud. (2013). Kompetensi Dasar Sekolah Dasar (SD)/Madrasah Ibtidaiyah (MI). Jakarta: Pusat kurikulum.

[13] Kemendikbud. (2017). Direktorat Pembinaan SMA. Direktorat Jendral Pendidikan Dasar dan Menengah: Jakarta.

[14] Khoiri \& Supriyanti. (2017). Analisis Kemampuan Berpikir Kritis Siswa Menggunakan Team Assisted Individualization. Science Education Journal, 1(2), 61-71.

[15] Munandar, U. (2014). Pengembangan Kreativitas Anak Berbakat. Jakarta: Rineke Cipta.

[16] Nenestalia, Y., \& Aslamiah. (2018). Meningkatkan Aktivitas Siswa pada Tema Keanekaragaman Makhluk Hidup menggunakan Kombinasi Model Problem Based Learning dikombinasikan dengan Jigsaw dan Make a Match pada Siswa Kelas 5 SDN Mawar 8 Banjarmasin. Banjarmasin: FKIP Universitas Lambung Mangkurat.

[17] Norfuad, \& Suriansyah, A. (2019). Implementasi Model Group Investigation, Mind Mapping dan Scramble untuk meningkatkan aktivitas belajar materi pengolahan data pada siswa kelas 5 SDN Teluk Dalam 3 Banjarmasin. Banjarmasin: FKIP Universitas Lambung Mangkurat.

[18] Nurmala, D., \& Suriansyah, A. (2017). Meningkatkan Aktivitas Belajar Siswa Materi Keputusan Bersama menggunakan Kombinasi Model Group Investigation, Numbered Heads Together dan Scramble pada Siswa Kelas 5 SDN Semangat Dalam 1 Barito Kuala. Banjarmasin: FKIP Universitas Lambung Mangkurat.

[19] Putra, T. T., Irwan, \& Vionanda, D. (2012). Meningkatkan Kemampuan Berpikir Kreatif dengan Pembelajaran Berbasis Masalah. Jurnal Pendidikan Matematika, 1(1), 22-26.

[20] Pratiwi, D. A., \& Sofiawati, N. (2018). Problem Solving Learning, Think Pair and Share (TPS) based on Audio Visual Media Improving Oral Activities. 1st International Conference on Creativity, Innovation and Technology in Education (IC-CITE 2018) (pp. 54-59), Banjarmasin, Atlantis Press.

[21] Rachmawati, Y., \& Kurniawati, E. (2010). Strategi Pengembangan Kreativitas Anak Usia Taman KanakKanak. Jakarta: Prenada Media Group. 
[22] Sani, R. A. (2015). Inovasi Pembelajaran. Jakarta: PT Bumi Aksara.

[23] Shoimin, A. (2014). 68 Model Pembelajaran Inovatif dalam Kurikulum 2013. Yogyakarta: Ar-Ruzz Media.

[24] Sholehah, \& Asniwati. (2017). Meningkatkan Aktivitas dan Hasil Belajar PPKn Materi Keputusan Bersama Muatan menggunakan Kombinasi Model Group Investigation, NHT dan Team Games Tournament pada Siswa Kelas 4 SDN Sungai Miai 11 Banjarmasin. Banjarmasin: FKIP Universitas Lambung Mangkurat.

[25] Sibarani, R. (2013). Pembentukan Karakter Berbasis Kearifan Lokal. Retrieved October, 1, 2020, from http:// www.museum.pusaka-nias.org/2013/02/pembentukankarakter-berbasiskearifan.html.

[26] Silver, E. A., \& Pittsburgh. (1997). Fostering creativity through instruction rich in mathematical problem solving and problem posing. Springer, 75-80.

[27] Sumarmo, U., \& Nishitani, I. (2010). High level mathematical thinking: Experiments with high school and under graduate students using various approaches and strategies. Bulletin of the Faculty of Education, Gunma University, 58(9), 9-22. Retrieved October, 1, 2020, from https://gair.media.gunma-u.ac.jp/ dspace/bitstream/10087/5130/1/03Nishitani.pdf.

[28] Suparlan. (2005). Menjadi Guru Efektif. Yogyakarta: Hikayat Publishing.
[29] Suriansyah, A. (2018). Membangun Pendidikan Berkualitas Berbasis Budaya Kerja Bermutu. Pidato Pengukuhan Guru Besar, Universitas Lambung Mangkurat. Banjarmasin: Universitas Lambung Mangkurat

[30] Tendrita, M., Mahanal, S., \& Zubaidah, S. (2016). Pemberdayaan Keterampilan Berpikir Kreatif melalui Model Remap Think Pair Share. Yogyakarta: Hikayat Publishing.

[31] Uno, H. B., \& Mohamad, N. (2012). Belajar dengan Pendekatan PAILKEM: Pembelajaran Aktif, Inovatif, Lingkungan, Kreatif, Efektif, Menarik. Jakarta: Bumi Aksara.

[32] Wagner, T. (2010). Overcoming the Global Achievement Gap. Cambridge: Harvard University.

[33] Yundiapi, S. Z., \& Aslamiah. (2018). Meningkatkan Hasil Belajar Tema Ekosistem Muatan IPA Menggunakan Model Discovery Learning dikombinasikan dengan SAVI dan TGT pada Siswa Kelas 5 SDN Benua Anyar 4 Banjarmasin. Banjarmasin: FKIP Universitas Lambung Mangkurat.

[34] Zubaidah, S. (2017). Keterampilan Abad ke-21 Keterampilan yang Diajarkan Melalui Pembelajaran. Conference Paper Seminar Nasional Pendidikan dengan tema "Isu-isu Strategis Pembelajaran MIPA Abad 21, STKIP Persada Khatulistiwa Sintang, West Kalimantan. 